\title{
Peremajaan Kawasan Kampung Bandeng Tambakrejo Semarang berdasarkan Preferensi Kelompok Usaha Masyarakat
}

\section{Urban Renewal Settlement Kampong Bandeng Tambakrejo Semarang Based on Preference of Business Community}

\author{
Yuwananabdha Syahbi Syagata ${ }^{\mathrm{a}}$, Rina Kurniati ${ }^{\mathrm{b}}$ * \\ ${ }^{a}$ Mahasiswa Universitas Diponegoro, Semarang, Indonesia \\ ${ }^{b}$ Dosen Universitas Diponegoro, Semarang, Indonesia
}

\begin{abstract}
Abstrak
Kampung Bandeng Tambakrejo dahulu merupakan pusat industri bandeng kalangan menengah, sangat disayangkan saat ini kawasan tersebut mengalami penurunan kualitas secara fisik maupun aktifitas. Proses produksi kampung bandeng sangat terganggu dengan keadaan fisik dan alam yang tidak memadai sehingga beberapa kelompok usaha saja yang bertahan untuk mengembangkan usaha bandeng tersebut. Tujuan keberlanjutan kampung bandeng tersebut mendorong untuk melakukan sebuah penelitian berupa arahan peremajaan kawasan kampung bandeng Tambakrejo berdasarkan preferensi kelompok usaha masyarakat.Metode penelitian yang digunakan dalam penelitian ini adalah penelitian kualitatif. Pengumpulan data dilakukan dengan menggunakan wawancara kepada narasumber, observasi dan dokumentasi. Data pada penelitian ini di dapat melalui wawancara kepada narasumber yang sudah ditentukan atau purposive sampling kepada anggota kelompok bandeng serta yang masih aktif dalam kegiatan produksi pengolahan bandeng dan udang dan sesepuh kampung yang mengetahui pertumbuhan kampung serta keberlanjutan fisik dan non fisik arahan peremajaan kampung bandeng berdasarkan Permen PU No. 02/PRT/M/2016 tentang peningkatan kualitas terhadap perumahan kumuh dan permukiman kumuh. Hasil penelitian membuktikan bahwa terdapat identifikasi fisik berupa bangunan gedung, jalan lingkungan, drainase, air bersih, air limbah, persampahan, dan pengamanan kebakaran serta aspek non fisik pada kampung bandeng yaitu pada kegiatan produksi, perdagangan jasa dan kegiatan sosial kemasyarakatan yang menunjang kegiatan kampung yang dianalisis dalam bentuk zonasi peremajaan kawasan berdasarkan preferensi kelompok usaha masyarakat. Arahan peremajaan kampung bandeng ini dapat menjadi sebuah pendekatan kepada masyarakat serta pemerintah dalam bentuk peremajaan dari masyarakat kampung bandeng Tambakrejo untuk merujuk kepada pemerintah. Bentuk zonasi tersebut ada 5 zonasi yang akan diremajakan, yaitu ada zona permukiman yang menampung masyarakat yang terdampak peremajaan kawasan, zona perdagangan dan jasa terdapat pada jalan arteri sekunder, zona produksi dan edukasi sesuai dengan preferensi masyarakat terletak di jalan Tanggungrejo Raya, dan Zona Ruang Terbuka publik guna meningkatkan bina sosial dalam peningkatan kegiatan sosial kemasyarakatan.
\end{abstract}

Kata kunci: Peremajaan Kawasan, Preferensi Kelompok Usaha Masyarakat, Kampung Bandeng Tambakrejo.

\begin{abstract}
Kampung Bandeng Tambakrejo used to be the center of the middle-class milkfish industry, it is unfortunate that currently the area is experiencing a decline in quality both physically and activity. The production process of Bandeng village is very disturbed by inadequate physical and natural conditions, so that only a few business groups have survived to develop the milkfish business. The sustainability goal of the bandeng village is to conduct a research in the form of rejuvenation direction for Tambakrejo Bandeng village based on community business group preferences. The research method used in this study is qualitative research. Data collection is done by using interviews with resource persons, observation and documentation. The data in this study were obtained through interviews with determined resource persons or purposive sampling to bandeng group members as well as those who were active in the production of
\end{abstract}

\footnotetext{
* Corresponding author. Author's Name.

E-mail address: ruang@pwk.undip.ac.id.
} 
milkfish and shrimp processing and village elders who were aware of village growth and physical and non-physical sustainability of milkfish village rejuvenation directions based on Permen PU No. 02 / PRT / M / 2016 about improving the quality of slums and slums. The results of the study prove that there are physical identifications in the form of buildings, environmental roads, drainage, clean water, waste water, solid waste, and fire safety as well as non-physical aspects in Bandeng villages, namely production activities, trade services and social activities that support village activities. analyzed in the form of regional rejuvenation zones based on the preferences of community business groups. The direction of the rejuvenation of the milkfish village can be an approach to the community and the government in the form of rejuvenation from the community of the bandeng Tambakrejo village to refer to the government. The zoning forms are 5 zones that will be rejuvenated, namely there are settlement zones that accommodate the people affected by regional rejuvenation, trade zones and services found on secondary arterial roads, production and education zones in accordance with people's preferences located on the Tanggungrejo Raya road, and the Open Space Zone public in order to increase social development in increasing community social activities.

Keyword: Urban Renewal, Preference of Business Community, Kampong Bandeng Tambakrejo.

\section{Pendahuluan}

Kota Semarang memiliki topografi yang berbeda yaitu terdiri dari daerah perbukitan, dataran rendah dan daerah pesisir. Perbedaan topografi tersebut membuat Kota Semarang sering disebut sebagai Kota Semarang bawah dan atas. Perkembangan Semarang bagian atas cenderung pada permukiman, sedangkan di daerah bawah hingga pesisir perkembangan cenderung pada permukiman dan industri. Kota Semarang dapat dikatakan sebagai kota tepi air atau waterfront city karena berada pada salah satu titik jalur utama Pantai Utara (Pantura) Pulau Jawa sekitar 1,8 juta populasi manusia hidup di wilayah pesisir (Rahardjo, 2000). Letaknya yang berada di jalur lalu lintas ekonomi tersebut menjadikan kota ini berkembang sebagai daerah potensial untuk aktivitas industri, perdagangan dan jasa, serta permukiman. Kota Semarang bagian utara telah banyak mengalami penurunan muka tanah dikarenakan banyak tumbuhnya permukiman yang tidak teratur dan industri yang kurang bersifat berkelanjutan sehingga muka air laut yang semakin tinggi yang diakibatkan dari amblesan, air laut masuk dari sungai menuju ke saluran drainase permukiman itu yang disebut dengan Rob (Marfai \& King, 2007).

Peremajaan kawasan merupakan upaya dan kegiatan pembangunan yang terencana untuk mengubah atau memperbaharui suatu kawasan terbangun di kota yang sudah merosot fungsinya agar kawasan tersebut fungsinya meningkat lagi sesuai dengan arah pengembangan kota. Berdasarkan SK Walikota Semarang Nomor 050/801/2014 mengenai kampung kumuh di Kota Semarang. Pemerintah kota semarang memiliki suatu upaya untuk menciptakan kesejahteraan penduduk yang lestari dan dapat berimplikasi dengan daerah lain yaitu dengan pembuatan kampung tematik. Karakterisktik permukiman kumuh yaitu mempunyai degradasi kualitas permukiman dan perumahan yang tidak standar, dikatakan tidak standar karena kondisi bangunan memiliki kepadatan tinggi, tidak teratur, tidak memenuhi syarat, syarat yang dimaksud adalah kondisi sarana dan prasarana permukiman tidak memenuhi keciptakaryaan yaitu berupa jalan lingkungan, drainase lingkungan penyediaan air bersih atau air minum, pengelolaan persampahan, pengelolaan air limbah, dan proteksi kebakaran yang sangat minim bahkan semua itu hampir tidak ada.

\section{Metode}

Pada metode penelitian ini menggunakan teknik analisis deskriptif kualitatif yang berfungsi untuk melihat preferensi kelompok usaha masyarakat dalam pengelolaan kampung bandeng yang terjadi dilapangan dengan melihat teori yang ada. Teknik analisis deskriptif kualitatif merupakan teknik analisis yang digunakan melalui wawancara, observasi langsung, dokumentasi, dan telaah dokumen, selanjutnya data- data tersebut diolah dan dianalisis menjadi informasi yang lebih mudah dimengerti. Sehingga hasil analisis ini yaitu deskripsi dan uraian mengenai apakah Kampung Bandeng Tambakrejo dapat berlanjut sebagai kampung industri pengolahan bandeng berdasarkan peremajaan kawasan serta preferensi kelompok usaha masyarakat. Wawancara yang dilakukan dalam penelitian ini dilakukan dengan cara bertatap muka langsung kepada narasumber terkait dalam penelitian agar memperoleh data-data 
atau informasi secara mendetail. Narasumber yang akan diwawancara adalah ketua Kelompok Usaha Bandeng Tambakrejo, Pelaku usaha Bandeng, Pelaku Usaha Udang, Instansi Pemerintah Kelurahan Tambakrejo. Analisis yang digunakan dalam penelitian ini termasuk analisis berupa prediksi studi kasus. Hal ini dikarenakan dalam penelitian akan melihat apakah peremajaan kawasan kampung bandeng Tambakrejo berdasarkan preferensi kelompok usaha masyarakat dapat mengelola dan menunjang keberlanjutan kampung bandeng Tambakrejo untuk menjaga kampungnya berupa bentuk-bentuk peremajaan yang dilakukan. Peremajaan kawasan dilakukan dalam tribina yaitu bina lingkungan, sosial dan usaha pada kelompok usaha masyarakat kampung bandeng Tambakrejo. keempat sasaran tersebut akan dianalisis dengan melakukan sistem reduksi, penyajian dan verifikasi data yang diperoleh dari wawancara untuk mengetahui preferensi kelompok usaha masyarakat dalam proses peremajaan kampung bandeng Tambakrejo. Format coding hasil wawancara dibentuk bertujuan untuk menentukan penulisan dan memudahkan peneliti dalam menandai hasil wawancara untuk analisis atau pembahasan dalam penelitian. Sehingga hasil wawancara dapat di interpretasi dan penggunaan data lebih mudah didalam analisis. Berikut merupakan form kategori variabel/tema dan subtema yang telah dibuat oleh peneliti.

Tabel 1 Form Kategori Variabel/Tema (Analisis Penulis, 2018)

\begin{tabular}{ccc}
\hline Uraian Hasil Wawancara & Sub Tema & Tema \\
\hline Pertanyaan:.... & Sarana (L1) & Lingkungan (L) \\
Jawaban:... & Prasarana (L2) & \\
\hline Pertanyaan:.... & Kelitas (L3) & Kemampuan Sosial (KS) \\
Jawaban:... & Kelompok Uandeng (KS1) & \\
& Institusi Pemerintah (KS3) & \\
\hline Pertanyaan:.... & Preferensi (KU1) & Keberlanjutan Usaha (KU) \\
Jawaban:... & Peremajaan (KU2) & \\
& Keseimbangan (KU3) & \\
\hline
\end{tabular}

\section{Kajian literatur}

Peremajaan kota (Urban Renewal) dikenal sebagai peremajaan kawasan terbangun kota yang berupaya untuk menata kembali kawasan tertentu dengan tujuan mendapatkan nilai tambah yang memadai sekaligus dapat mempertahankan kelestarian fungsi dan kualitas lingkungannya (Danisworo, 1988). Menurut Eko Budihardjo, kota yang berkelanjutan kiranya dapat disebutkan sebagai berikut: Kota yang dalam perkembangan dan pembangunannya mampu memenuhi kebutuhan masyarakat masa kini, mampu berkompetisi dalam ekonomi global dengan mempertahankan keserasian lingkungan vitalitas sosial, budaya, politik dan pertahanan keamanannya, tanpa mengabaikan atau mengurangi kemampuan generasi mendatang dalam pemenuhan kebutuhan mereka (Budiharjo, 1999:27).
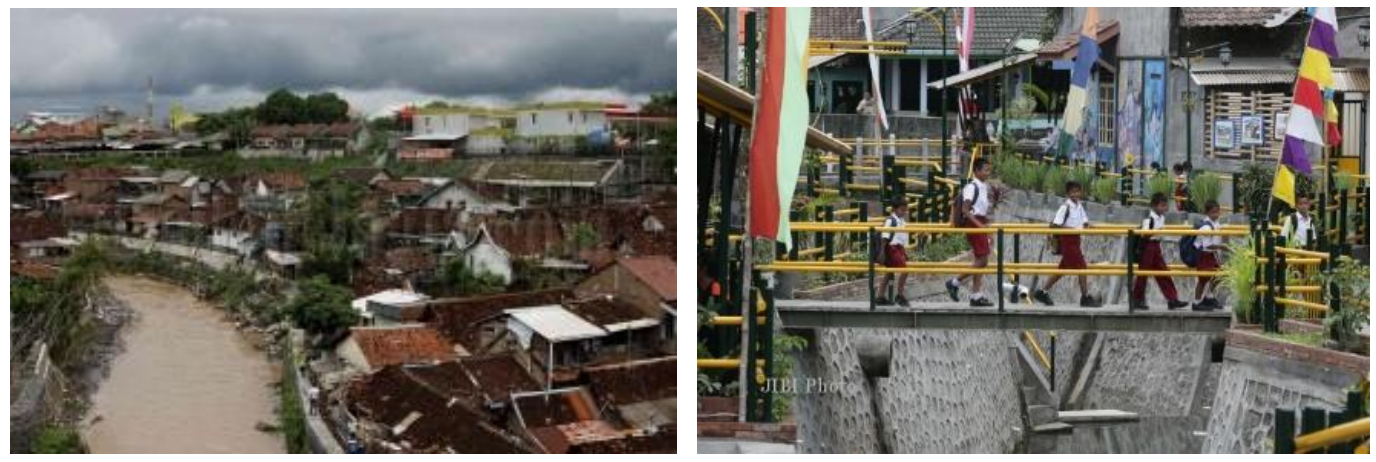

Gambar 1. Peremajaan Kawasan Gemblakan Bantaran Kali Code Yogyakarta (Pemkot Yogyakarta, 2018 
Ada beberapa tindakan yang dapat dilakukan berkaitan dengan upaya peremajaan pada suatu lingkungan (Samidjo, 2014) yaitu :

a. Pembangunan kembali (Redevelopment), merupakan upaya penataan kembali suatu kawasan kota dengan melakukan pembongkaran sarana dan prasarana pada sebagian atau seluruh kawasan tersebut terlebih dahulu yang telah dinyatakan tidak dapat dipertahankan lagi kehadirannya. Pada kegiatan ini terjadi perubahan struktural terhadap peruntukan lahan, profil sosial ekonomi, serta ketentuan-ketentuan pembangunan lainnya yang mengatur intensitas pembangunan baru.

b. Rehabilitasi merupakan upaya mengembalikan kondisi suatu bangunan atau unsur-unsur kawasan kota yang telah mengalami kerusakan, kemunduran, atau degradasi sehingga dapat berfungsi kembali sebagaimana mestinya. Preservasi merupakan upaya memelihara dan melestarikan lingkungan pada kondisinya yang ada, serta mencegah terjadinya proses kerusakan. Metode ini biasanya diterapkan pada obyek yang memiliki arti sejarah atau arti arsitektur tertentu.

c. Resettlement adalah proses pemindahan penduduk dari lokasi permukiman yang sudah tidak sesuai dengan peruntukkannya ke lokasi baru yang sudah disiapkan sesuai dengan rencana permukiman kota.

Didalam UU No. 4 Tahun 1992 tentang Perumahan dan Permukiman, Pasal 27 ayat (2) menyatakan bahwa kegiatan yang dilakukan dalam rangka peningkatan kualitas permukiman meliputi upaya melalui perbaikan atau pemugaran, peremajaan serta pengelolaan dan pemeliharaan yang berkelanjutan. Upaya yang dilakukan dalam rangka peremajaan yaitu dengan kesatuan upaya Tribina (3 Fokus) memiliki arti setiap paket bantuan memperhatikan tatanan sosial kemasyarakatan, penataan lingkungan fisik dan kualitas hunian serta pengembangan kegiatan usaha ekonominya.

Setiap kegiatan yang dilakukan diarahkan pada suatu proses pemampuan, penggalian sumber daya lokal serta pemberian peran yang lebih besar (Pemberdayaan) kepada masyarakat untuk berperan sebagai pelaku utama (leading actors). Selaintu Perhatian dan keberpihakan dengan menempatkan aspirasi, kepentingan serta keputusan masyarakat sebagai acuan penyusunan program dan kegiatan. Salah satu kunci dalam upaya meremajakan kawasan permukiman perkotaan ini adalah penyediaan lahan yang dapat menjamin keberadaan masyarakat untuk tetap dekat dengan lingkungan/sumber pendapatannya.

Percepatan proses memukimkan masyarakat yang memerlukan rumah yang lebih layak dan lingkungan yang lebih tertata dan prospektif secara berkelanjutan. Proses ditempuh melalui cara yang terjangkau dengan memperhatikan kemampuan ekonomi masyarakat antara lain fasilitasi penyediaan rumah sewa, penyediaan bantuan dana bergulir untuk memugar rumah. Melalui KEPPRES No. 05 Tahun 1992 Pemerintah memfasilitasi proses pemukiman kembali masyarakat yang tinggal di permukiman kumuh di atas tanah negara.

\section{Hasil dan Pembahasan}

\section{Preferensi Masyarakat dalam Mewujudkan Keberlanjutan Kampung}

Peremajaan kawasan kampung bandeng Tambakrejo berdasarkan Preferensi Masyarakat yaitu lebih mengarah kepada keberlanjutan para pelaku usaha. Pada wawancara penelitian ini, narasumber yang merupakan pelaku usaha memberikan sebuah penjelasan mengenai kebutuhan fisik dan fasilitas yang masyarakat butuhkan mengenai keberlanjutan usahanya. Preferensi masyarakat akan dilihat melalui permintaan kebutuhan dalam kelompok usaha bandeng. Permintaan akan digambarkan oleh jumlah yang diminta akan kebutuhan dan harapan masyarakat akan kelompok usaha. Sesuai dengan teori permintaan, ada banyak faktor yang mempengaruhi permintaan (Sukirno, 2005). Preferensi masyarakat disini akan dikategorikan dalam dua sisi pandangan untuk menunjang kekuatan kelompok usaha bandeng dan pengupasan udang, yaitu kebutuhan masyarakat dan harapan masyarakat, berikut penjelasannya:

1. Kebutuhan Masyarakat

a. Produksi: Pengolahan Bandeng, Pengolahan Tahu Bakso, Pengolahan Pengupasan Udang Pengolahan Keripik Ikan

b. Limbah Produksi: Pengolahan Limbah Cair dan Padat

c. Sentra Distribusi: Pool parkir pengambilan hasil produksi untuk di ekspor ke luar daerah maupun ke luar negeri 
d. Sentra Konsumsi: Sentra Pemasaran untuk penjualan ke konsumen sebagai peminat dalam industri Bandeng dekat dengan tempat produksi

e. Sentra Edukasi: "Pengolahan, Quality Control, Limbah, semua secara trasnparan terbuka untuk publik, sebagai sarana edukasi untuk masyarakat mengetahui cara industri pengolahan bandeng kukus, pepes, presto, pengupasan udang, pembuatan keripik ikan dan kerupuk udang." (KU/10/66)

Berdasarkan analisis preferensi masyarakat untuk keberlanjutan usaha ditemukan beberapa keinginan dan harapan masyarakat dalam melakukan upaya keberlanjutan usahanya dan keberlanjutan untuk kepentingan kelompok masyarakat pada lingkungan kampung Bandeng Tambakrejo. Dari hasil observasi dan wawancara simpulan wawancara tersebut membutuhkan sebuah identifikasi secara fisik untuk menunjang kelengkapan data yang dilakukan saat wawancara. Identifikasi tersebut akan dilanjutkan pada analisis kriteria peremajaan kawasan kampung bandeng Tambakrejo untuk mengetahui kriteria apa saja yang dibutuhkan kemudian dilakukan analisis peremajaan kawasan kampung bandeng Tambakrejo guna menjawab permasalahan yang ada di lingkungan permukiman tersebut.

Tabel 2 Sintesa Analisis Preferensi Masyarakat dan Peraturan Menteri Pekerjaan Umum (Analisis Penulis, 2018)

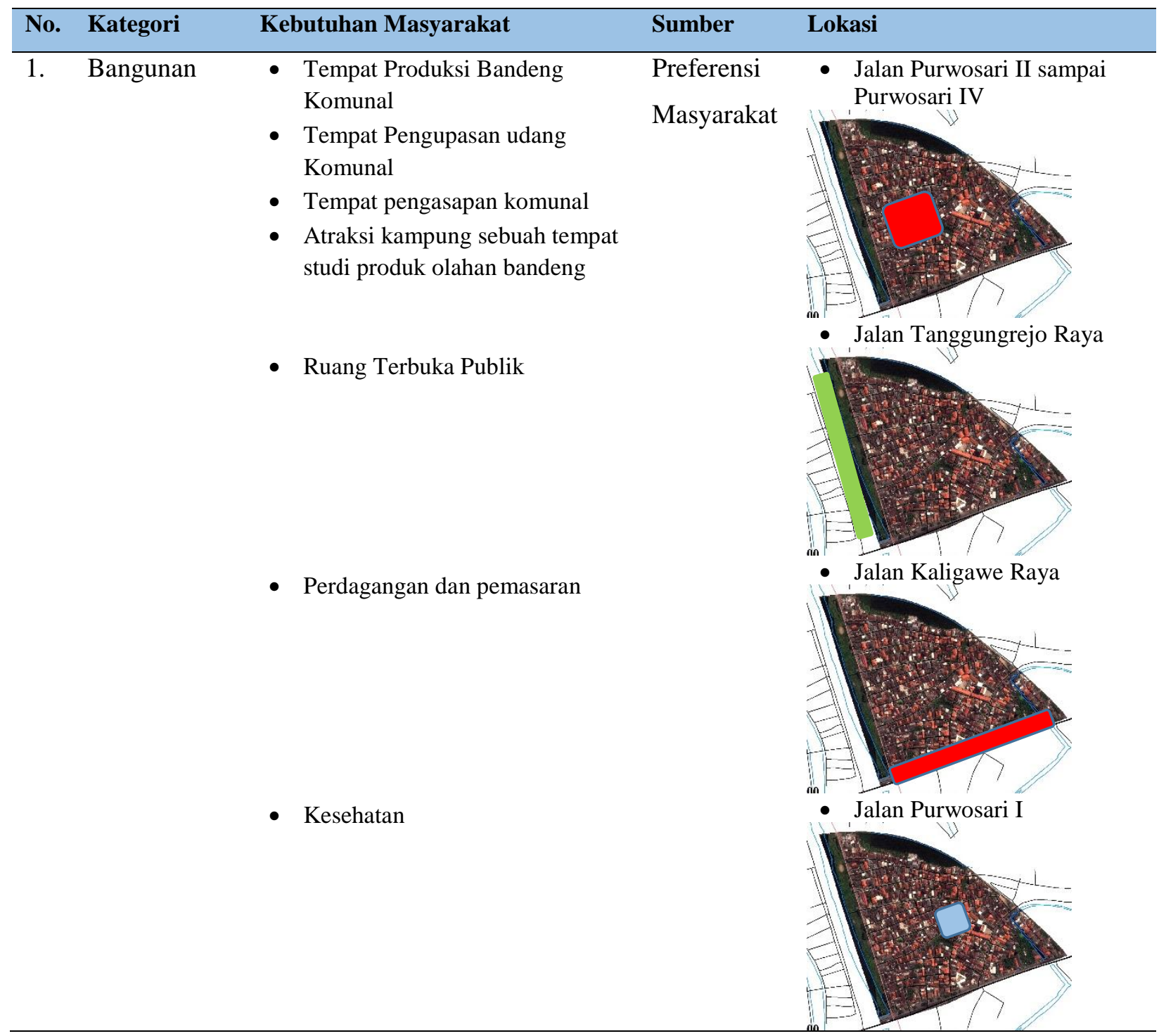




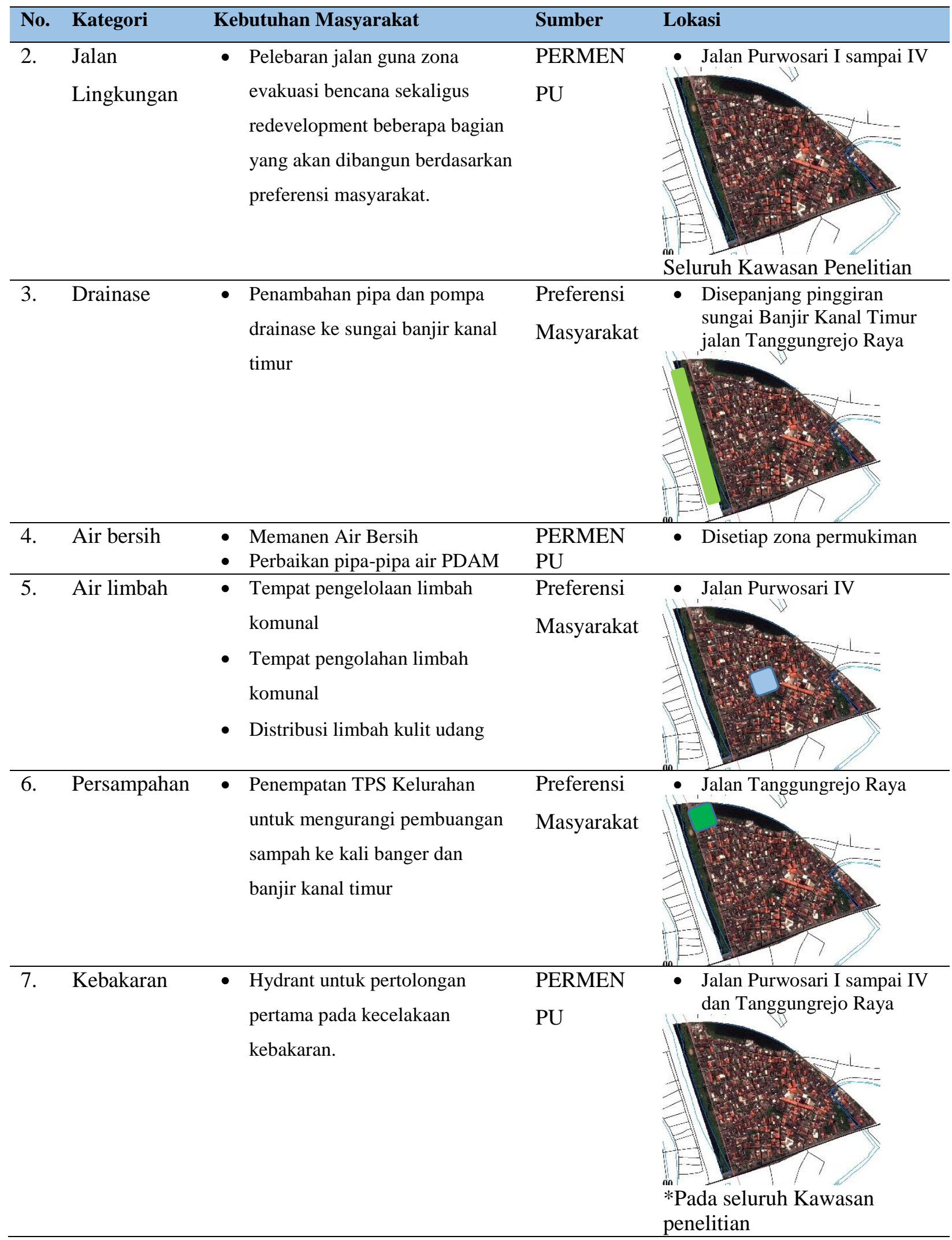

Sumber: Hasil Analisis Penulis, 2018

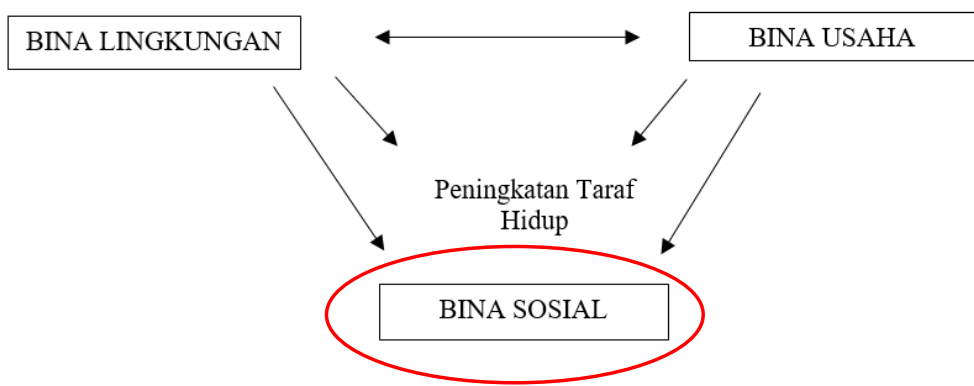


2. Analisis Fisik dan Non-Fisik Kawasan Kampung Bandeng Tambakrejo

a. Analisis Fisik

- Sarana lingkungan merupakan aspek penting dalam menunjang sebuah kegiatan sebuah kampung. Adapun sarana yang akan diremajakan antara lain Pengolahan limbah, Ruang Terbuka Publik, Perdagangan dan jasa, Pemasaran, peribadatan, kesehatan dan transportasi (Permen PU No. 2 PRT/M/2016 dan Narasumber).

- Prasarana Lingkungan merupakan aspek penting bagi peremajaan kawasan pada pembahasan ini akan dianalisis kelayakan Kampung Bandeng Tambakrejo berdasarkan ketersediaan prasarananya berupa jaringan jalan, jaringan air bersih,jaringan listrik.

- Utilitas kampung Bandeng tersebut masih dalam keadaan yang berantakan dan tidak teratur dengan baik, dalam penempatannya ataupun dalam penggunaannya masih dalam kategori yang sederhana. Pada kenyataannya utilitas kampung bandeng sebagai industri olahan masih kurang memadai, dengan luasan yang hanya 10 meter persegi dan kepemilikan yang dimiliki perseorangan yang memiliki hak dalam usaha tersebut yang menjadikan tempatnya sebagai tempat komunal, namun yang dibutuhkan dalam hal ini satu kampung untuk proses produksi pengolahan bandeng, udang, tahu bakso yang masih bertahan pada kampung bandeng tersebut.

b. Analisis Non-Fisik

- Atraksi Kampung Bandeng

Atraksi pelanggan tersebut terdiri dari pusat pengolahan bandeng, sentra bandeng, kampung semarang pusat oleh-oleh yang cukup menarik bagi sebagian besar masyarakat apabila mau oleh-oleh khas Semarang yang murah langsung dari produsennya ya disini tempatnya.

- Pemasaran

Lokasi pemasaran yang masih belum mempunyai atraktif pada pelanggan dan belum sesuai peletakkannya, masyarakat berupaya untuk menyesuaikan dengan kebutuhan dan penempatannya lokasi sentra pemasaran lebih terlihat dan menjadi gerbang awal menuju sarana edukasi untuk sentra industri pengolahan.

Apabila dihubungkan oleh Tribina masyarakat analisis tersebut termasuk kedalam bina lingkungan, yang membuat perubahan terhadap lingkungan kampung bandeng sebagai bentuk improvement.

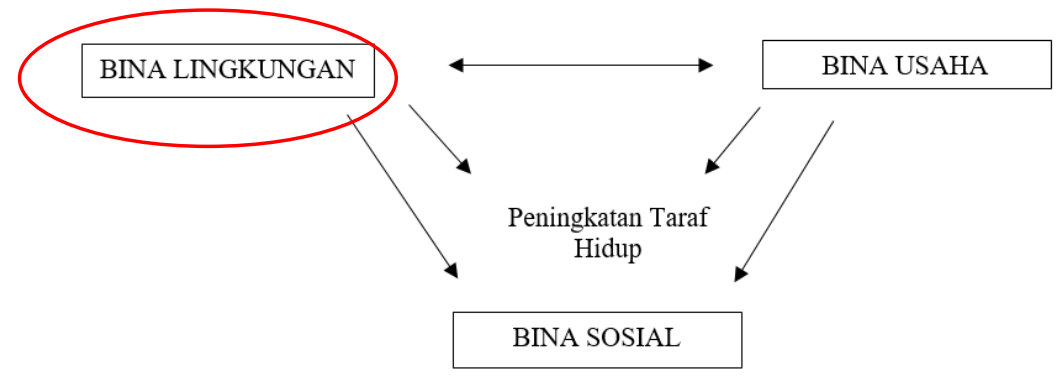

Analisis bentuk-bentuk peremajaan yang dilakukan dengan analisis Zonasi

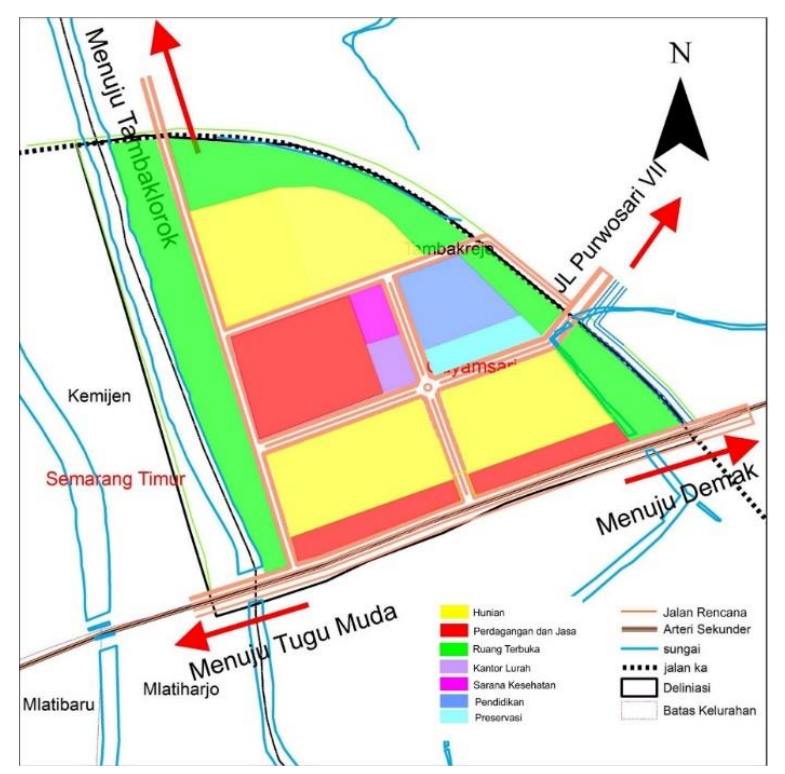

Gambar 2. Peta Zonasi Kawasan (Analisis Penulis, 2018) 
Berdasarkan peta zonasi peremajaan kawasan, dapat diketahui bahwa terdapat lima zona yang ada pada peremajaan kawasan kampung bandeng Tambakrejo yaitu zona permukiman, zona perdagangan dan jasa, zona pengolahan, zona pendidikan dan zona ruang terbuka hijau. Pemanfaatan ruang tersebut dilakukan berdasarkan kepentingan dan kebutuhan yang berbasis pada preferensi masyarakat sesuai dengan ketentuan peraturan sistem zonasi nasional. Selanjutnya pada masing-masing zona tersebut akan dilakukan upaya peremajaan kawasan pada khususnya untuk zona permukiman yang menggunakan permukiman yang bersifat berkelanjutan, namun dengan penguatan zona-zona penunjang yang lain merupakan sebuah upaya untuk kampung yang berkelanjutan dengan memiliki kelompok masyarakat yang kuat dalam usaha industri pengolahan yang sebelumnya berbasis rumah tangga kemudian dilanjutkan berbasis kampung, perdagangan dan jasa guna melakukan sebuah pemasaran yang atraktif dengan dimanfaatkan sebagai rekreasi. Berawal dari analisis preferensi kelompok usaha masyarakat ditambahkan oleh Peraturan Menteri Pekerjaan Umum Perumahan Rakyat ada beberapa kesimpulan sebelum masuk kedalam analisis zoning pada siteplan yang akan dijelaskan selanjutnya. Masyarakat berkecenderungan untuk melakukan pembinaan usaha terlebih dahulu untuk melakukan peremajaan pada lingkungan dan sosial, dikarenakan kebutuhannya yang dilirik pada kepentingan pembangunan tambahan fasilitas usaha untuk keberlanjutan usaha kampung bandeng Tambakrejo..

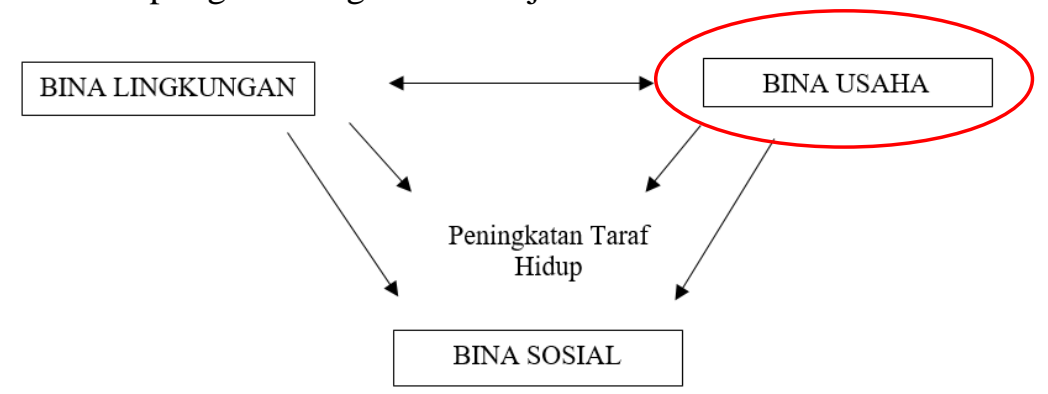

Berdasarkan analisis yang telah dilakukan berawal dari analisis preferensi masyarakat, analisis fisik dan non fisik peremajaan kawasan kampung bandeng Tambakrejo, analisis Zonasi peremajaan kawasan kampung bandeng berdasarkan preferensi masyarakat, maka diperolah hasil berupa arahan pengembangan peremajaan Kawasan Kampung Bandeng Tambakrejo. Upaya gambaran peremajaan kawasan tersebut memiliki sebuah artian pengimplementasian kebutuhan masyarakat dalam upaya peremajaan kawasan. Sebuah penjabaran gambar dilakukan untuk menjelaskan detail-detail gambar yang ingin dikembangkan masyarakat Tambakrejo guna keberlanjutan kampung bandeng Tambakrejo. Berikut sintesa hasil dari gambaran bentuk peremajaan kawasan yang dilakukan pada kampung bandeng Tambakrejo. Berdasarkan pola tribina, bina lingkungan dilakukan beberapa pembangunan secara bertahap yaitu bentuk-bentuk pelebaran jalan serta redevelopment kampung bandeng, bina usaha dan bina sosial berupa preferensi masyarakat untuk penambahan fasilitas yang ada untuk kepentingan kampung.

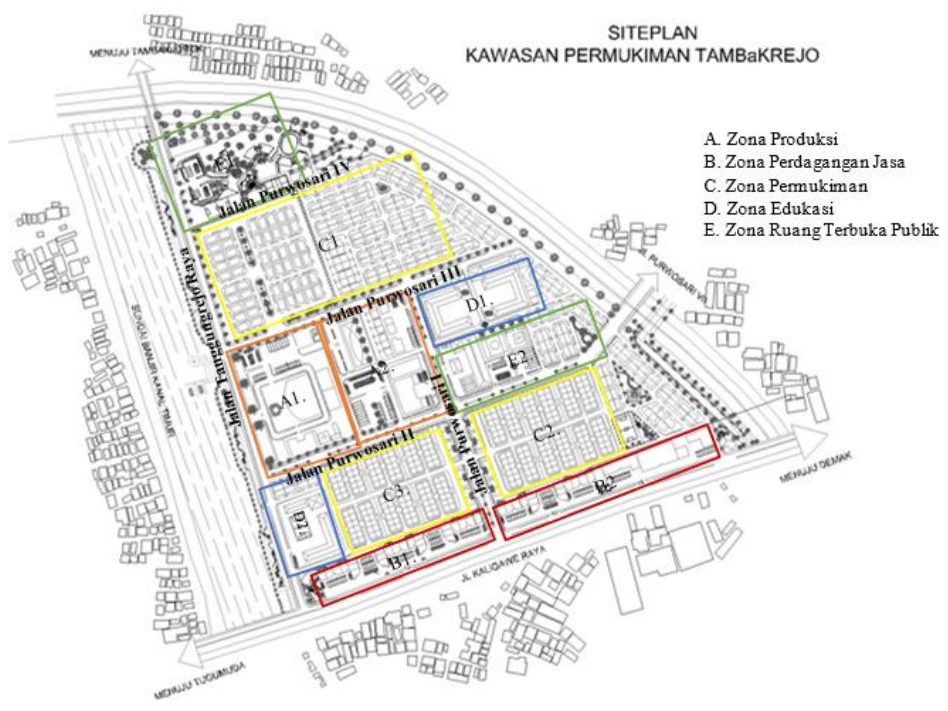

Gambar 3. Siteplan Kawasan Permukimanan Tambakrejo 


\section{Kesimpulan}

Kampung Bandeng Tambakrejo merupakan salah satu dari lingkungan kawasan kumuh yang terdapat di kota Semarang. Kampung Bandeng Tambakrejo memiliki potensi berupa kesamaan dalam penjualan produk olahan bandeng dan olahan udang. Dari produk tersebut membuat Kampung Bandeng menjadi salah satu kampung unggulan tematik Kota Semarang untuk melakukan peremajaan kawasan dalam aspek sosial kemasyarakatan. Arahan peremajaan kawasan yang berbasis kelompok usaha bersama bandeng ini menjadikan kelompok usaha di kelurahan Tambakrejo mempunyai bekal untuk menjadi kampung yang berkelanjutan berbasis kelompok usaha masyarakat kelurahan Tambakrejo. Berdasarkan hal tersebut didapati beberapa kesimpulan yaitu sebagai berikut:

Preferensi masyarakat merupakan kebutuhan masyarakat dalam hal peremajaan kawasan yang dibutuhkan untuk dilakukan sebuah proses peremajaan yang sesuai dengan preferensi masyarakat. Masyarakat membutuhkan beberapa sarana dan prasarana yang setidaknya butuh untuk keberlanjutan usaha yang sudah dirintis yaitu pengolahan bandeng dan pengupasan udang. Sarana dan prasarana yang dibutuhkan tersebut adalah tempat produksi dan pengolahan yang komunal, pemasaran produk, ruang terbuka yang lebih dikedepankan. Untuk prasarana berupa jalan, drainase dan pengolahan limbah cair maupun padat yang mampu mengolah menjadi barang jadi di kawasan kampung Bandeng Tambakrejo. Ketiga, Arahan peremajaan kawasan kampung bandeng Tambakrejo berdasarkan preferensi masyarakat. Dari beberapa aspek yang dianalisis kemudian ditemukan analisis zonasi kampung bandeng Tambakrejo berdasarkan preferensi masyarakat tersebut memunculkan 5 zonasi yaitu:

- Zonasi perumahan terdiri dari 3 zona perumahan yang merupakan hasil dari penataan kawasan yang mencakupi seluruh kawasan Kampung Bandeng Tambakrejo yang fungsi tersebut murni guna perumahan berkepadatan tinggi dengan tipe rumah panggung guna keberlanjutan kawasan dan meminimalisir peninggian rumah akibat penurunan muka tanah

- Zonasi perdagangan dan jasa memiliki 2 persebaran zonasi yang merupakan lokasi strategis dari wilayah kampung bandeng Tambakrejo yaitu dipinggir jalan raya kaligawe dengan konsentrasi lalu lintas kendaraan yang tinggi dan sekeliling sentra kampung bandeng yang merupakan atraktif bagi kampung tersebut sekaligus untuk kepentingan promosi sekaligus edukasi.

- Zonasi pengolahan dibutuhkan untuk adanya pengolahan produk olahan ikan bandeng dan udang dilokasi tersebut sekaligus pengolahan limbah padat dan cair sisa hasil dari produk olahan tersebut yang diolah kembali dapat digunakan untuk barang jadi seperti make up dari kulit udang itu sendiri dan hiasan dari sisik ikan yang akan ada seksi tersendiri untuk produk pengolahan limbah

- Zonasi edukasi merupakan bagian dari edukasi dari proses dari produk pengolahan ikan bandeng dan udang sampai pengolahan limbahnya yang menjadi sebuah nilai tambah dari lingkungan kampung bandeng

- Zonasi ruang terbuka hijau di lokasi tersebut dibutuhkan dikarenakan lingkungan kampung bandeng Tambakrejo yang minim akan ruang terbuka hijau yang difungsikan sebagai sarana rekreasi kawasan kampung bandeng dengan alasan untuk memperindah kawasan, zonasi tersebut terletak pada sepanjang bantaran sungai kanal banjir timur dan sempadan rel kereta api trek ganda.

Aspek peremajaan kawasan kampung bandeng Tambakrejo berdasarkan preferensi masyarakat dengan menggunakan pola Tribina dari buku panduan permukiman kumuh direktorat jendral cipta karya kementerian PUPR terdapat 3 aspek yang mendasari penelitian ini yaitu bina lingkungan, bina sosial dan bina usaha atau dalam penelitian ini yaitu kelompok usaha bersama olahan bandeng dan udang memiliki kecenderungan pada bina usaha yang ada pada kelompok usaha tersebut sebagai dasar pada peremajaan kawasan. Kemudian dari bina usaha tersebut dapat dilakukan bina lingkungan berupa perubahan pada peremajaan kawasan. Untuk tahap selanjutnya diiringi dengan pembinaan pada sosial kemasyarakatan agar terjalin lebih baik. Dikarenakan adanya pembinaan terhadap usaha dan perubahan peningkatan kualitas lingkungan di Kampung Bandeng Tambakrejo tersebut yang ketiganya tertuang pada gambaran peremajaan Kampung Bandeng Tambakrejo. Dari semua analisis akan ditemukan aspek-aspek penting peremajaan kawasan dengan sebuah keluaran usulan peremajaan kawasan yang 
menggambarkan kondisi berdasarkan preferensi masyarakat kampung bandeng Tambakrejo dari analisis zonasi dikeluarkan menjadi sebuah gambaran tapak bangunan-bangunan sesuai analisis zonasi yang sudah dianalisis. Redevelopment kampung bandeng guna memaksimalkan jalur evakuasi dan pelebaran jalan selebar 4 meter, kemudian dilakukan pembangunan fasilitas berdasarkan kebutuhan kelompok usaha pada kampung bandeng Tambakrejo.

\section{Referensi}

Budihardjo, Eko . 1999. Kota Berkelanjutan. Penerbit Alumni. Bandung

Danisworo, Muhammad.1988.Teori Perancangan Urban, Program Studi Perancangan Arsitektur Pasca Sarjana ITB: Bandung.

Keputusan Presiden Nomor 5 Tahun 1992 tentang BENDA CAGAR BUDAYA

Peraturan Pemerintah No.62 tahun 2010 tentang pemanfaatan pulau-pulau kecil terluar

Peraturan Presiden No.78 tahun 2005 tentang pengelolaan pulau-pulau kecil terluar

Peraturan Menteri Kelautan dan Perikanan No.20 tahun 2008 tentang pemanfaatan pulau-pulau kecil dan perairan di sekitarnya

Peraturan Menteri Agraria dan Tata Ruang / Kepala BPN No. 17 tahun 2016 tentang penataan pertanahan di wilayah pesisir dan pulau-pulau kecil.

Rahardjo, T. (2000). The Semarang Environmental Agenda: A stimulus to targeted capacity building among the stakeholders. Habitat International, 24(4), 443-453. https://doi.org/10.1016/S01973975(00)00009-6

Samidjo, J. (2014). Peremajaan Kota Sebagai Alternatif Upaya Perlindungan Lingkungan Perkotaan Berkelanjutan. Jurnal Ilmiah Pawiyatan, 21(2), 92-106.

Surat Keputusan Walikota 050/801/2014 tentang penetapan lokasi lingkungan perumahan dan permukiman kumuh Kota Semarang

Undang-Undang No. 17 tahun 2007 tentang Rencana Pembangunan Jangka Panjang Nasional dalam hal Kota Tanpa Permukiman Kumuh

Undang-Undang No.1 tahun 2014 tentang perubahan UU No. 27 tahun 2007 mengenai pengelolaan wilayah pesisir dan pulau-pulau kecil

Undang-Undang No. 1 Tahun 2011 tentang Perumahan dan Kawasan Permukiman

Undang-Undang No. 4 Tahun 1992 tentang Perumahan dan Permukiman

Undang-Undang No. 17 tahun 2007 tentang Rencana Pembangunan Jangka Panjang Nasional dalam hal Kota Tanpa Permukiman Kumuh dengan upaya pencegahan dan peningkatan kualitas kawasan permukiman 